which several parts have appeared, and I understand that some MSS, remain to be published.

It is pleasant to reflect that so much good work was not allowed to pass unrecognised. In addition to the distinctions already mentioned, many others were conferred upon him. Ward became a Fellow of the Linnean Society in I886, and was elected a Fellow of the Royal Society in $\mathrm{x} 888$, receiving a Royal medal in 1893; he served on the council of the Linnean Society, I887-9, and on that of the Royal Society, I895-6. He was elected an honorary fellow of Christ's College, Cambridge, in 1897, and in 1902 received the degree of D.Sc. honoris causa from his first Alma Mater, the Victoria University, having previously taken the same degree at Cambridge. $\mathrm{He}$ was president of the British Mycological Society, I900-2, and had received the honorary fellowship of the Manchester Literary and Philosophical Society and of other societies.

Beginning in 1854 at Hereford, his life is a story of unremitting and successful effort until its close at Torquay on Sunday, August 26, rgo6. I remember Ward as a genial companion, a man of varied interests, delighting especially in music; but the dominant impression is that of his whole-hearted devotion to his science; all else counted with him as nothing in comparison with that. No doubt this led him to impose too severe a strain upon a constitution never very robust: but such as he was, it could not have been otherwise. He was laid to rest in the Huntingdon Road Cemetery, Cambridge, on September 3, attended by many friends and colleagues, amid tokens of regret from near and far.

S. H. VINES.

\section{CHARLES BARON CLARKE, F.R.S.}

THE death of Mr. Charles Baron Clarke on August 25, in his seventy-fourth year, deprives the botanical world of an able worker, and takes from a wider circle still a friend endeared for his breadth of sympathy and charm of manner.

Born at Andover in 1832, Clarke was educated at King's College School, London, and at Trinity and Queens' Colleges, Cambridge. He graduated in 1856 being bracketed third wrangler. Elected a fellow of Queens' in 1857 , he was in 1858 called to the Bar at Lincoln's Inn, and appointed mathematical lecturer of his college. This position he held until $186_{5}$, when he joined the Bengal Educational Department.

While at Cambridge Clarke was one of a brilliant group holding advanced economic views, which included Henry Fawcett, Leslie Stephen, and John Rigby. His interest in political economy continued throughout his life, and found expression in occasional pamphlets on economic subjects, which he treated in a manner pleasing for its lucidity and freedom from political bias.

Before he left England, Clarlze, as a recreation, was interested in field botany. On reaching India he printed at Calcutta, in I866, a list of the plants of Andover, his birthplace. Clarke began his Indian career as a teacher in the Presidency College, Calcutta, but soon became an inspector of schools. His work as inspector involved touring within the circle allotted to him, and gave him facilities for botanical field work. Of these he made the utmost use, and supplemented them by vacation visits to districts outside his circle and provinces beyond Bengal. He made extensive collections, and at the same time found material for contributions to ethnology and geography. From 5869 until I87I Clarke was in charge of the Royal Botanic Garden at Calcutta, with the use of a well-equipped herbarium at his command. The administrative work of these two years left little time for publication of results, but, on reverting to his own department, Clarke, while as ardent a collector as ever, found time to commence the issue of his valuable contributions to Eastern botany. His monographs of the Indian Cyrtandraceæ and Commelynaceæ were issued in 1874 ; that of the Indian Compositæ appeared in 1876. In the former year also, Clarke, at his own risk and cost, issued a new and cheap edition of Roxburgh's "Flora Indica," which had become almost unprocurable.

The extent and value of the field work done by Clarke during the first ten years of his Indian service may be best measured by the character of the collection presented by him to Kew in 1877 . This included 25,000 numbers, representing some 5000 species. The fulness of the notes, often accompanied by useful analyses; the precise indication of localities and altitudes; the excellence of the specimens themselves, combine to render this contribution one of the most munificent additions ever made to the Indian material at Kew. It represents journeys in the Bengal plain, on the Chutia Nagpur plateau, in Chittagong, in the Khasia Hills, in Sikkim from the Terai to the snows, in the Punjab Himalaya, in Kashmir and thence to the Karakoram, in the Nilgiri Hills. No botanist since Griffith had seen more of India; none since Hooker had more fully examined the areas visited.

Early in 1879 Clarke was placed on special duty in England, and for four years was engaged at Kew assisting Sir Joseph Hooker in the preparation of the "Flora of British India "; for the second, third, and fourth volumes of this work he prepared the accounts of many important natural families. While in England Clarke also published, in 1880 , a review of the "Ferns of Northe.n India." He returned to India early in 1883 , and towards the close of 1884 he was appointed to act as Director of Public Instruction, Bengal. In 1885 his services were transferred from Bengal to Assam, a change of province which admitted of his further exploration of the Surma and Brahmaputra valleys and of the Khasia and Jaintia Hills, and enabled him to make a botanical journey in the Naga Hills and Manipur, new ground even for him, the results of which were published in the Journal of the Linnean Society.

In 1887 Clarke retired from the Indian Service and settled at Kew, so as to be near the herbarium there, in which he worked for nineteen years as a volunteer. Early in his Indian career he appears to have been particularly attracted to the study of the Cyperaceæ, and one of the objects of his life was the completion of a general monograph of this difficult family, with regard to which Clarke became the recognised authority to whom botanists in every country sent their collections for identification and description. His devotion to this group, accounts of which he prepared for the "Flora of British India," the "Flora Capensis," and the "Flora of Tropical Africa," was not, however, exclusive, for he elaborated several important families for both the African "Floras" and for the "Flora of the Malay Peninsula," and communicated numerous botanical papers to the I.innean and Royal Societies.

Clarke joined the Linnean Society in I867, when his active botanical work in India first began. In the society's fortunes he took the keenest interest, being, while on special duty in England and again since his retirement, one of the most trusted councillors of the society, over which he presided from I894 until I896. He was elected a Fellow of the Royal Society in $\mathbf{I} 882$, and served on the council in I888-9. He was also a Fellow of the Geological and of the Geographical Societies.

No. I 924 , vOL. 74] 